жодному разі не можуть замінити викладача. Роль педагога залишається провідною, і лише від нього залежить якість отриманих знань студентів: від уміння зацікавити та організувати студентів, від акторської майстерності проводити заняття, якості дібраних матеріалів. Тому традиційне навчання доцільно доповнювати новітніми засобами навчання.

\title{
Література
}

1. Long-Term Experiences in Mathematics E-Learning in Europe and the USA / Sven Trenholm, Angel A. Juan, Jorge Simosa, Amilcar Oliveira, Teresa Oliveira // Teaching Mathematics Online: Emergent Technologies and Methodologies / Edited by Angel A. Juan, Maria A. Huertas, Sven Trenholm, Cristina Steegmann. - Hershey : Information Science Reference, 2012. - Р. 238--257. 2. Новиков С. П. Применение новых информационных технологий в образовательном процессе / С. П. Новиков // Педагогика. - 2003. -№ 9. - С. 32-38.

УДК 378.147

Олександр Коновал, Тетяна Туркот

\section{НОВІ КОНЦЕПТУАЛЬНІ ПІДХОДИ ДО ОРГАНІЗАЦІЇ САМОСТІЙНОЇ РОБОТИ СТУДЕНТІВ}

Коновал О. А., Туркот Т. І. Нові концептуальні підходи до організації самостійної роботи студентів

У статті здійснено аналіз змісту теоретико-методологічних (системного, аксіологічного, синергетичного) підходів до організації самостійної роботи студентів, обгрунтовано необхідність їх реалізації в сучасному освітньо-інформаційному середовищі вищого навчального закладу.

Ключові слова: самостійна робота студентів, системний, аксіологічний, синергетичний підходи.

Коновал А. А., Туркот Т.И. Новые концептуальные подходы к организации самостоятельной работы студентов.

В статье осуществлен анализ содержания теоретико-методологических (системного, аксиологического, синергетического) подходов к организации самостоятельной работы студентов. Обоснована необходимость их реализации в современной образовательноинформационной среде высшего учебного заведения.

Ключевые слова: самостоятельная работа студентов, системный, аксиологический, синергетический подходы.

Konoval O. A., Turkot T. I. New conceptual approaches to students' independent work organization.

The article is devoted to the analysis of the content of the theoretical and methodological (systemic, axiological, synergetic) approaches to the organization of students' independent work. The necessity of their realization in the modern educational and informational environment of higher educational establishment has been substantiated.

Key words: students' independent work; systemic, axiological, synergetic approaches.

Перехід до постіндустріального, інформаційного суспільства, докорінні економічні, політичні та соціальні зміни, що відбуваються в Україні, зумовлюють потребу підготовки нової генерації вчителів, вихователів, науково-педагогічних працівників. Цей чинник вимагає визначення концептуальних довгострокових стратегій розвитку і вдосконалення вищої освіти, системоутворювльним складником яких $є$ ідея безперервного навчання, оскільки процес формування професійних якостей і здібностей повинен відбуватися безперервно упродовж життя [8; 14]. «Програма навчання протягом життя» (Life long learning), запропонована Європейською комісією, передбачає формування восьми ключових компетенцій, якими повинен володіти кожен європеєць, серед яких обов'язковою виокремлюється навчальна компетенція як здатність та уміння навчатись [8]. У зв'язку з цим актуалізується проблема вдосконалення системи організації самостійної роботи студентів-майбутніх педагогів, яка б формувала здатність особистості до творчого саморозвитку, самоосвіти, самоактуалізації як підгрунтя інноваційної педагогічної чи науково-педагогічної діяльності. Ця тенденція є 
типовою для університетів країн світової спільноти, ураховуючи й Україну, в навчальних планах яких, за даними ЮНЕСКО, частка самостійної роботи студентів становить 50-70 \%. Дослідженнями О. Малихіна [12], Г. Кільової [7], І. Сулим [15; 16; 17] доведено, що саме самостійна робота особистості має бути не просто важливою формою освітнього процесу, а повинна стати його основою. У зв'язку з цим метою статті визначено висвітлення сутності концептуально нових теоретико-методологічних підходів до організації самостійної роботи студентів (СРС), які б забезпечили її ефективність та оптимальність результатів.

Зазначимо, що за відомим словником В. Даля термін «підхід» тлумачиться як «йти під гору будь-чого», «бути підгрунтям чого-небудь». У нашому дослідженні ми дотримуємося педагогічної інтерпретації поняття «підхід», запропонованого Л. Велипченко, як апріорну думку про сутність досліджуваного явища, якісний суб'єкт і логічний предикат якого утворюють вихідну посилку в теоретико-емпіричному аналізі. Перетворення логічного предикату на систему суджень $є$ підгрунтям для побудови імпліцитної теоретичної моделі явища, що вивчається [2, с. 75].

Підкреслимо насамперед, що нові концептуальні підходи до організації СРС грунтуються на гуманістичній парадигмі, яка окреслює своїм головним орієнтиром формування цілісної особистості майбутнього педагога в процесі його саморозвитку. Принцип гуманізму i гуманістичний підхід [3, с. 76-77], як логічні похідні гуманістичної концепції, згідно з законами України про освіту та вищу освіту [1], є основою функціонування сучасної загальноосвітньої та вищої шкіл, є віссю, навколо якої можна об'єднати концептуальні підходи до організації навчального процесу у вищому навчальному закладі i, зокрема, до самостійної роботи студентів як невід'ємного складника цього процесу. Ця робота повинна організовуватися на засадах системного, аксіологічного та синергетичного підходів, які складають теоретико-методологічне ядро системи сучасних концептуальних підходів до організації самоосвітньої діяльності.

Із позицій філософії освіти системний підхід дозволяе розглядати будь-яке педагогічне явище як єдине ціле, що складається з системи взаємопов'язаних частин (елементів), надає змогу пояснювати зміст і цінність кожного елемента як самостійного об'єкта у його діалектичній єдності з цілісністю педагогічного процесу [6, с. 22].

На засадах системного підходу нами була запропонована нова модель організації самостійної діяльності студентів в інформаційно-освітньому середовищі сучасного ВНЗ, елементами якої визначаються: концепція, принципи організації СРС, ії мета, зміст, методи та дидактичні засоби, спрогнозовані умови забезпечення результативності цієї діяльності [11]. Передбачається, що під час переходу від етапу до етапу самостійної роботи мають реалізовуватися мотиваційно-цільова та когнітивна компоненти особистісно-професійного розвитку майбутнього фахівця, повинні здійснюватися систематичний контроль і оцінювання знань та умінь студентів, набутих у процесі самоосвітньої роботи. Отже, систему організації СРС слід розглядати як органічну цілісність компонентів, що характеризуються взаємозв'язками, єдністю функціонування та внутрішньою упорядкованістю, яка спрямована на досягнення основної мети та цілісно інтегративного результату - досягнення студентами оптимальних навчальних результатів i формування здібностей до самоактуалізації, самореалізації та самовдосконалення.

Аксіологічний підхід (від грец. aksia - цінність, logos - вчення) [3, с. 21] передбачає формування ціннісних орієнтацій, настанов і мотивів самостійної навчальної діяльності майбутнього вчителя [4]. Аксіологічна, ціннісно-мотиваційна спрямованість навчального процесу у ВНЗ передбачає усвідомлення студентом мотивів самостійної роботи, усвідомлене визначення іï мети, вибір форм, методів та відповідного інструментарію i, зокрема, використання нових інформаційних технологій при самостійному опрацюванні навчального матеріалу. Аксіологічний складник сприяє прийняттю студентом тих, чи інших рішень у галузі самоосвіти, відіграє роль своєрідного саморегулятора навчальної діяльності майбутнього педагога (вчителя, викладача ВНЗ), визначає його професійні інтереси й особистісні настанови, впливає на формування професійно-особистісних рис, особливо значущих для ефективного управління самостійною діяльністю учнів.

Ми вважаємо, що однією із стрижневих позицій організації самостійної позааудиторної роботи студентів $\epsilon$ проблема мотивації навчально-пізнавальної діяльності їх, оскільки загальновідомо, що саме мотиви $є$ рушійною силою розвитку особистості. Управління 
мотивами поведінки студента, здійснюване $з$ урахуванням його особистісно-психологічних характеристик, відкриває широкі можливості для виваженої оцінки ним своїх здібностей і дозволяє спрямувати молоду людину на вибір оптимальної індивідуальної траєкторії в організації самостійної роботи. Підкреслимо, що у своїй динаміці мотиви неможливо розглядати без взаємозв'язку з цілепокладенням. Ми повністю погоджуємося 3 поглядами Р. Тайлера, який підкреслював, що саме в мотиваційній спрямованості самостійної роботи визначаються чинники, які істотно впливають на підвищення чи зниження ефективності самостійної навчальної діяльності студента на шляху до реалізації поставлених цілей, формування його навчального досвіду [18]. Обов'язковим елементом вивчення мотивів і змін, які відбуваються у структурі навчальної діяльності студентів, $є$ вивчення спрямованості цілей у процесі самоорганізації самостійної позааудиторної роботи. Важливим постає розуміння не того, як майбутній вчитель чи викладач ВНЗ в межах академічно-традиціоналістичного підходу розв'язує запропоновані йому завдання, а те, які завдання він сам поставив перед собою, плануючи самостійну роботу. Отже, на основі аксіологічного підходу можна створити принципово нову стратегію освіти й самоосвіти: формування у майбутніх педагогів механізмів модифікації мотиваційно-ціннісних аспектів власної самостійної діяльності через процеси самопізнання.

Так, вивчаючи досвід організації самостійної позааудиторної роботи студентів педагогічних колективів США, І. Сулим підкреслила, що мотиваційно-цільова спрямованість особливо чітко виявляється в моделях «прогресивного навчання» (Р. Томас, В. Перрі) та «значущого навчання» (Р. Джонсон), які реалізуються засобами організації СРС за індивідуальними планами, системою вивчення предметів за вибором, гнучким модульним розкладом занять, системою навчальних планів, призначених для індивідуального самостійного навчання [17, c.116-117]. Накопичений у США досвід проведення педагогічної практики доводить, що реалізація аксіологічного підходу може позитивно впливати на мотиваційну сферу студента, його інтелектуальні процеси, пробуджувати в нього творче ставлення до самостійної діяльності та творчого розв'язання актуальних соціально-педагогічних проблем [15; 16; 17].

Організації самостійної роботи студентів на засадах теорії самоорганізації складних систем сприяє синергетичний підхід (від давньогрецького «синергія»- співдія, співпраця). [9] На думку В. Маткіна, виникнення синергетики як науки, можливо, знаменує початок наукової революції, бо вона не просто впроваджує нову систему понять, але й змінює стратегію наукового пізнання та сприяє становленню нової наукової картини світу [13]. Зазначимо, що синергетичний підхід до освіти принципово важливо використовувати в організації СРС, особливості якої з позицій синергетизму - це більший ступінь свободи планування, самокорекції навчальної діяльності, взаємодії його учасників на засадах ініцюючої освіти та співробітництва. Так, аналізуючи світоглядні ідеї синергетики, Є. Князєва підкреслює: «...процедура навчання, засіб зв'язку зв'язків того, хто навчається, з тим, хто навчає, учня та вчителя - це не відтворювальне перекладення знань, не повідомлення і подання готових істин. Це нелінійна ситуація відкритого діалогу, прямого і зворотного зв'язку солідаристичної освітньої пригоди, у якій опиняється внаслідок розв'язання проблемних ситуацій в один самоузгоджений темп освіти. Це ситуація пробудження власних сил і здібностей того, хто навчається, ініціююча або пробуджувальна освіта, відкриття себе або співробітництво з самим собою та іншими людьми» [9, с. 12].

У сучасному освітньо-інформаційному середовищі реалізація синергетичного підходу уможливлюе ефект посилення впливів навчальної інформації, що надходить до студента 3 різних джерел і через різні канали сприйняття [5; 10]. Так, системне використання комп'ютерних дидактичних засобів відкриває перед студентами більш широкі можливості для самостійного отримання оперативної інформації, необхідної для засвоєння програмного матеріалу та матеріалу, що виходить за межі навчальної програми, створює сприятливі умови для обміну знаннями в сучасному освітньому просторі, забезпечення ефекту кумуляції (рис.). Побудова дидактичного процесу 3 використанням комп'ютерних засобів навчання (інформаційні сайти інститутів, кафедр, електронні навчально-методичні комплекси дисциплін (НМКД), розсилання завдань для самостійної роботи, участь в онлайн-конференціях, вебінарах i т. д.) дозволяє значно активізувати самостійну роботу студентів, створює комфортний режим для самоосвіти, зменшує непродуктивні витрати часу, наприклад, на проведення рутинних математичних розрахунків та ін. 
Кумулятивний ефект використання системи комп'ютерних дидактичних засобів у самоосвітній роботі знаходить вияв у таких процесах як:

- явище резонансу, коли інформація отримана самостійно, стимулює швидкі та суттєві зміни в системі знань, накопичених на лекційних чи семінарсько-практичних заняттях;

- явище акселерації, що характеризує прискорення активності особистості та результативності самостійної роботи студента за умови забезпечення творчого інформаційноосвітнього середовища;

- явище інтеграції - об’єднання самостійно отриманих знань з різних джерел у єдину систему.

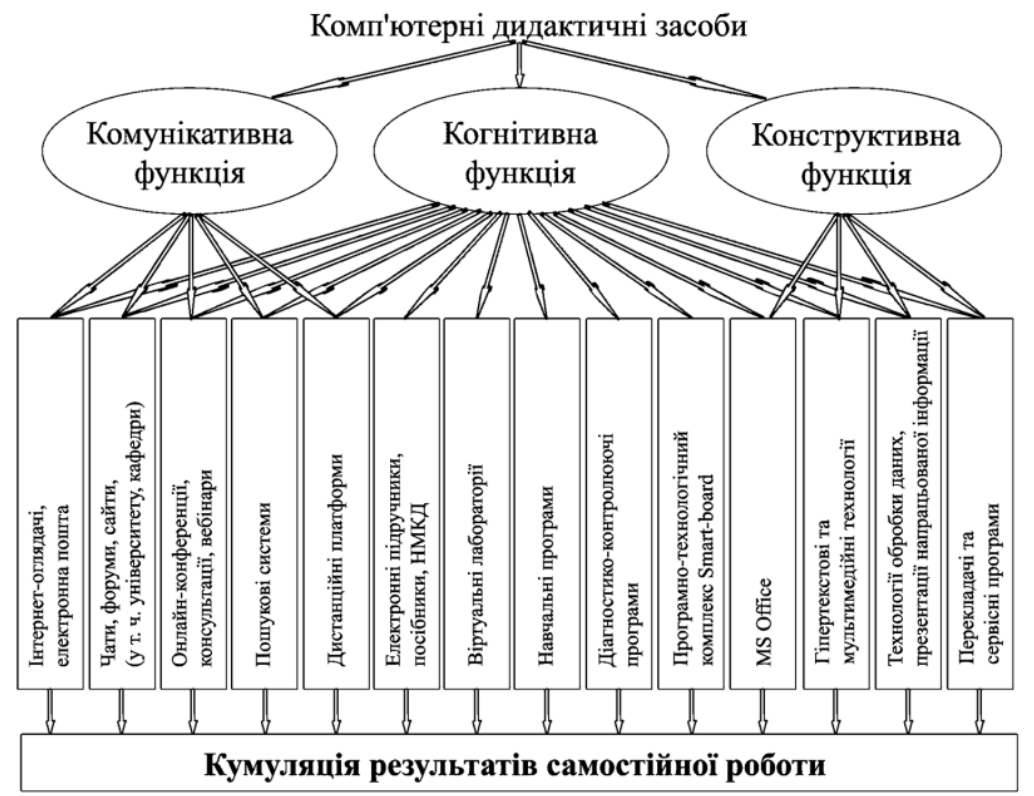

Рис. 1 Система комп'ютерних дидактичних засобів

Однією 3 медіатехнологій, необхідних для самостійного вивчення природничоматематичних дисциплін, $є$ віртуальні лабораторії. У віртуальних лабораторіях студенти можуть готуватися до лабораторних та практичних робіт, іспитів, заліків, олімпіад. Окрім того, у віртуальних лабораторіях можна відтворити багато природних явищ, лабораторних дослідів, неможливих для демонстрації в умовах навчальних закладів. До того ж користувач може змінювати параметри середовища i моделювати явища як результат своїх дій, що практикується під час вивчення спеціальної теорії відносності та електродинаміки студентами фізико-математичного факультету Криворізького педагогічного інституту. У процесі дослідноекспериментальної роботи, яка здійснюється творчою групою викладачів цього навчального закладу відповідно завдань проекту «Дидактичні засоби СРС», було визначено педагогічні умови забезпечення ефективності самостійної роботи студентів під час вивчення теоретичної фізики з використанням інформаційних технологій, а саме:

1) використання комп'ютера під час вивчення теоретичного матеріалу має бути педагогічно доцільним і орієнтованим на реалізацію конкретних дидактичних задач;

2) надання переваг комп'ютеру у порівнянні з традиційними засобами унаочнення повинне мати місце лише у випадках, коли

3) використання інформаційних технологій має незаперечний педагогічний ефект, досягнення якого засобами традиційних підходів викликає труднощі чи потребує більших часових витрат; 
4) перевірка правильності виконання математичних обчислень до практичних чи лабораторних робіт ускладнена через рутинність та громіздкість;

5) якщо специфіка матеріалу для самостійного вивчення передбачає виконання складних побудов, креслень і графіків, якість і точність яких впливає на засвоєння та розуміння змісту теми, то переадресування цих функцій комп'ютера є виправданим і педагогічно доцільним;

6) текстова або графічна інформація, подана з використанням комп'ютера, не вимагає від студента переписування, а допомагає здійснити копіювання 3 подальшим зберіганням на магнітних носіях;

7) зміст лекційного матеріалу, адаптований до умов інформаційних технологій, може бути відтворений у вигляді друкованого видання або розповсюджений шляхом електронних комунікацій на досить віддалені території і використаний студентами для самостійного опрацювання.

Основними організаційними умовами для успішного використання комп'ютерної підтримки студентів у самоосвітній діяльності визначаємо такі:

- їх вільний доступ до Інтернету у аудиторний та позааудиторний час;

- їхнього уміння працювати в Інтернет-мережі, знання спеціальних програмних продуктів, Інтернет- та мультимедійних технологій;

- організація викладацької діяльності на основі системного підходу до поділу функцій, коли основними спеціалізаціями викладачів визначаються:

а) фахівець із комп'ютерної презентації навчальних дисциплін, тобто дизайнер курсів;

б) консультант із методів навчання, або фасилітатор, який допомагає студентам знайти і реалізувати індивідуальну самоосвітню траєкторію;

в) тьютор, тобто фахівець з інтерактивного подання змісту навчальних курсів, консультант студентів у процесі самостійного вивчення навчальної дисципліни;

г) фахівець із методів контролю за результатами самостійного навчання, відповідальний за організацію і проведення тестів, заліків, іспитів, якого у міжнародному співтоваристві прийнято називати інвігілатером (анг. invigilate - стеження за тим, хто екзаменується).

Вище означені функції можуть виконуватися як однією людиною, так і різними людьми.

Підсумовуючи, зазначимо, що побудова системи самостійної роботи студентів у сучасному освітньо-інформаційному середовищі ВНЗ на засадах охарактеризованих у статті теоретикометодологічних підходів, сприятиме підвищенню іï ефективності. Перспективним напрямком подальших наукових розвідок має бути розроблення методико-праксілогічних підходів до організації СРС, які стануть підгрунтям активного упровадження до цього процесу системи сучасних дидактичних засобів.

\section{Література}

1. Закон України про вищу освіту // Вища школа. - 2002. - №6. - С. 74-120. 2. Велипченко Л. К. Методологічна сутність категорії підходу в наукових дослідженнях / Л. К. Велипченко // Педагогіка і психологія. - 2009. - №2 (63). - С. 72-79. 3. Гончаренко С. У. Український педагогічний словник / С. У. Гончаренко. - К. : Либідь, 1997. - 374 с. 4. Губа Н. В. Концептуальні підходи до формування управлінської культури / Н.В. Губа // Педагогіка і психологія. - 2008. - №2 (59). - С. 100-110. 5 Гуревич Р. С. Готовність до застосування інформаційно-телекомунікаційних технологій у педагогічній діяльності як основа компетентності учителя / Р.С. Гуревич // Наукові записки. Серія: Педагогіка і психологія. - 2006. - №16. - Вінницький державний педагогічний університет ім. Коцюбинського. - С. 222-225. 6. Ібатова А. 3. Системный подход к исследованию проблемы формирования готовности студентов к профессионально-ориентированному обучению на иностранном языке; Материалы научно-практической конференции [теоретические и методологические проблемы современной педагогической науки]. (1 июня 2009 г.) / А.З. Ибатова. Караганда : Центр гуманитарных исследований, 2009. - с.20-23. 7. Кільова Г. Післядипломна педагогічна освіта вчителів у контексті стратегії навчання упродовж життя / Г. Кільова // Післядипломна освіта в Україні. - 2012. - №1 (20) - С.20-23. 8. Ключові компетентності для навчання протягом життя - Європейська довідкова рамка / Затверджена рекомендацією Європейського парламенту та Європейської ради про ключові компетентності для навчання протягом життя (2006/962/СС) // Савченко О.Я. Дидактика початкової освіти: підручник - К.: Грамота, 2012. 504 с. - с.461-470. 9. Князева Е.Н. Синергетика как мировоззрение. Диалог с И. Пригожиным / Е.Н. Князева, С.П. Курдюмов // Вопр. философии. - 1992. - №12. - С.3-20. 10. Коновал О. А., Туркот Т. І. Комп’ютерні засоби підтримки самостійної пізнавальної діяльності майбутніх учителів фізики / О.А. Коновал, 
T.I Туркот // Наукові записки. Серія «Педагогічні науки». - Кіровоград : РВіД КДПУ ім. Винниченка, 2012. - Вип. 76. - ч.2 - С.138-143. 11. Коновал А. А., Туркот Т. И. Новая модель организации самостоятельной учебной деятельности студентов в современной информационно-образовательной среде вуза / Коновал Александр Андреевич, Туркот Татьяна Ивановна // Информация и образование: границы коммуникаций INFO, 11: Сборник научных трудов №4 (12). - Горно-Алтайск: РИО ГАГУ, 2012. - С.37-39. 12. Малихін О.В. Організація самостійної навчальної діяльності студентів вищих педагогічних навчальних закладів: теоретико-методологічний аспект: [монографія] / Олександр Володимирович Малихін. - Кривий Ріг: Видавничий дім, 2009. - 307 с. 13. Маткин В.В. Ценностносинергетический подход и его реализация в процессе педагогической подготовки будущих учителей / В.В. Маткин // Наука и школа. - 2001. - №6 - c.10-12. 14.Рахимов А.3. Педагогическая акмеология: наука о закономерностях достижения профессиональной вершины / Рахимов А.3. - Уфа : БашГПУ, 1999. - 246 с. 15. Сулим І.Ф. Методологічні засади організації самостійної роботи студентів педагогічних коледжів США / Сулим І.Ф. // Наукові записки. Серія: Педагогіка і психологія. Вінницький державний педагогічний університет ім. Коцюбинського, 2005. -№15. - С.116-119. 16. Сулим І.Ф. Структурування змісту освіти в процесі організації самостійної позааудиторної роботи студентів педагогічних коледжів США / І.Ф. Сулим // Наукові записки. Серія: Педагогіка і психологія. Вінницький державний педагогічний університет ім. Коцюбинського. - 2005. - №13. С.133-135. 17. Сулим І.Ф. Мотивація забезпечення самостійної позааудиторної роботи студентів педагогічних коледжів США / І.Ф. Сулим // Наукові записки. Серія: Педагогіка і психологія. Вінницький державний педагогічний університет ім. Коцюбинського. - 2005. - №12. - C.115-117. 18. Tyler R. Basic Principles of Corriculum and Justruction. - Chicago: Univ. of Chicago. Press, 1979. - 216 p.

УДК 377:614.253.5:174

Олена Кравченко

\section{ФОРМУВАННЯ ПРОФЕСІЙНОЇ ЕТИКИ МАЙБУТНІХ МЕДИЧНИХ СЕСТЕР У НАВЧАЛЬНО-ВИХОВНОМУ ПРОЦЕСІ МЕДИЧНОГО КОЛЕДЖУ: МЕТОДОЛОГІЧНІ ПІДХОДИ}

Кравченко О. П. Формування професійної етики майбутніх медичних сестер у навчальновиховному процесі медичного коледжу: методологічні підходи.

У статті схарактеризовано компетентнісний, культурологічний, аксіологічний підходи до формування професійної етики майбутніх медичних сестер. Запропоновано структурнозмістову модель та комплекс взаємопов'язаних педагогічних умов формування професійної етики майбутніх медичних сестер у навчально-виховному процесі медичного коледжу.

Ключові слова: професійна етика, майбутня медична сестра, компетентнісний, культурологічний, аксіологічний підходи.

Кравченко Е. П. Формирование профессиональной этики будущих медицинских сестер в учебно-воспитательном процессе медицинского колледжа: методологические подходы.

В статье охарактеризованы компетентностный, культурологический, аксиологический подходы к формированию профессиональной этики будущих медицинских сестер. Предложено структурно-содержательную модель и комплекс взаимосвязанных педагогических условий формирования профессиональной этики будущих медицинских сестер в учебновоспитательном процессе медицинского колледжа.

Ключевые слова: профессиональная этика, будущая медицинская сестра, компетентностный, культурологический, аксиологический подходы.

Kravchenko O. P. Formation of the future nurses ' professional ethics in the educational process of medical college: methodological approaches.

The article determined competence, cultural, axiological approaches to professional ethics of future nurses. Based on the above mentioned approaches structural and semantic model is proposed and a set of interrelated pedagogical conditions of formation of future nurses professional ethics in the educational process of medical college.

Key words: professional ethics, future nurse, competence, cultural, axiological approaches.

Сьогодення з його динамічним потоком інформації й мобільними технологіями вимагає від медичної сестри швидкого виконання маніпуляцій і володіння технічними засобами. Відтак 